\title{
Choline acetyltransferase detection in normal and denervated electrocyte from Electrophorus electricus (L.) using a Confocal Scanning Optical Microscopy Analysis*
}

\author{
NILSON NUNES-TAVARES ${ }^{1}$, NARCISA LEAL CUNHA-E-SILVA ${ }^{2}$ \\ and AÍDA HASSÓN-VOLOCH ${ }^{1}$ \\ ${ }^{1}$ Laboratório de Físico-Química Biológica \\ ${ }^{2}$ Laboratório de Ultraestrutura Celular Hertha Meyer, Instituto de Biofísica Carlos Chagas Filho \\ Universidade Federal do Rio de Janeiro, Centro de Ciências da Saude - 21491-590 Rio de Janeiro, RJ, Brasil
}

Manuscript received on April 18, 2000; accepted for publication on April 24, 2000; contributed by Aída Hassón-VoLOCH**

\begin{abstract}
Acetylcholine is the neurotransmitter responsible for the transmission of impulses from cholinergic neurons to cells of innervated tissues. Its biosynthesis is catalyzed by the enzyme Choline acetyltransferase that is considered to be a phenotypically specific marker for cholinergic system. It is well known that the regulation of Choline acetyltransferase activity under physiological and pathological conditions is important for development and neuronal activities of cholinergic functions. We observed the distribution of Choline acetyltransferase in sections from the normal and denervated main electric organ sections of Electrophorus electricus (L.) by immunofluorescence using a anti-Choline acetyltransferase antibody. The animals were submitted to a surgical procedure to remove about 20 nerves and after 30 and 60 days, they were sacrificed. After 30 days, the results from immunohistochemistry demonstrated an increase on the Choline acetyltransferase distribution at denervated tissue sections when compared with the sections from the normal contralateral organ. A very similar labeling was observed between normal and denervated tissue sections of the animals after 60 days. However, Choline acetyltransferase activity (nmolesACh/ $\mathrm{min} / \mathrm{mg}$ of protein) in extracts obtained from electrocyte microsomal preparation, estimated by Fonnun's method (Fonnun 1975), was $70 \%$ lower in the denervated extracts.
\end{abstract}

Key words: choline acetyltransferase, electrocyte, denervation, immunohistochemistry.

\section{INTRODUCTION}

Choline acetyltransferase (ChAT; EC 2.3.1.6) is the enzyme responsible for the biosynthesis of the neurotransmitter acetylcholine $(\mathrm{ACh})$ which was described by Nachmansohn and Machado in 1943. Many authors have pointed out that choline acetyl-

\footnotetext{
*Invited paper

** Member of the Academia Brasileira de Ciências

Correspondence to: Aída Hassón-Voloch

E-mail: adhasson@biof.ufrj.br
}

transferase is directly related to many types of neurological disorders such as Alzheimer disease, myasthenia gravis, multiple sclerosis, and Huntington's disease (Rossier 1977, Molenaar et al. 1981, Kato 1989). Thereafter, either purification as the study of the role of this enzyme in biological models has been object of considerable attention (Hersh \& Wu 1994, 1995, Rand et al. 1994, Salvaterra et al. 1995).

The electrogenic tissue from E. electricus (L.) is densely innervated with pure cholinergic nerve 
endings and differentiated histophysiologically in three electric organs: main, Hunter and Sachs (Couceiro \& Ackerman 1948, Esquibel et al. 1971). The electrocyte is the functional unit of the electric tissue (Schwartz et al. 1975) which, in turn, is essentially formed by a non innervated (anterior) and an innervated (posterior) face with numerous synapses, myelin fibers, and it is also rich in acetylcholine receptor molecules (Chagas et al. 1957, Couceiro \& Ackerman 1948, Couceiro et al. 1953).

Previous studies carried out by Esquibel et al. (1971) have demonstrated the structural organization of the electric organ from newborn E. electricus (L.) by using both optical and electron microscopy, resulting in the observation of myofibril-like structures in the cytoplasm of the developing electrocyte. However, in elder E. electricus (L.) these structures were not observed (Machado et al. 1976). An analogy between the electric organ and striated muscles has also been carried out since the electric organ presents important proteins of the energetic metabolism, found in muscle, such as creatine phosphokinase (Hazan-Carneiro \& Hassón-Voloch 1983), lactate dehydrogenase (Torres Da Matta et al. 1975) as well as cytoskeletal proteins like myosin and desmin (Costa et al. 1986, 1988).

Acetylcholine was the first neurotransmitter described (Loewi 1921) and plays a central role in fundamental processes as learning, memory, sleep (Bartus \& Beer 1982, Aigner \& Mishkin 1986) and muscle contraction in mammals. The electric organ has cholinergic neurons that innervate electrocytes growing from myotubes and have about 1,000 fold ACh receptors than muscle cells (Whittaker 1987). Recently, we described that most of ChAT found in the electrocyte is mainly present as cytosolic protein with two isoforms (Nunes-Tavares \& HassonVoloch 1998). Earlier studies showed that denervation of the main electric organ from E. electricus (L.) produced increases on RNA contents, RNA/DNA and RNA/protein ratio, which were observed by histochemistry studies, and aminoacid incorporation, although the total protein did not showed significant alteration (Falcato-Ribeiro \& Chagas 1975, Falcato-
Ribeiro et al. 1977). Denervation is a technique that can be used when we aim to study the interaction between muscles and nerves. After denervation, the electric organ shows a late and slow atrophy which allows the study of nerve control upon its structure (Martins-Ferreira \& Couceiro 1951). Histochemical and biochemical studies of denervated electrocytes, after 30 and 60 days, showed the disappearance of myelin sheath as well as the increase on the activity of some important enzymes of the energetic metabolism (Falcato-Ribeiro et al. 1977, 1980, Torres DaMatta et al. 1985). Other studies concerning neurodegenerative diseases, as Alzheimer and Parkinson, has demonstrated that the vesicular acetylcholine transporter (VAChT), and the high-affinity choline transporter (HAChT), may remain unchanged or, in some circumstances, increase in cortex and hippocampus over the control (Ruberg et al. 1990, Kuhl et al. 1996). Lesion paradigms in animals have been used to directly study the effects of the loss of cholinergic input and the response of cholinergic neurons to injury.

The present study describes the histochemical investigation of choline acetyltransferase (ChAT) distribution in normal and denervated electric organ by immunofluorescence under confocal microscopy (CSLM).

\section{MATERIAL AND METHODS}

Electrophorus electricus (L.). were provided to us by "Museu Emílio Goeldi, Belém do Pará - Brasil" and kept in an aquarium with fresh filtered water.

\section{IMMUNOCHEMICALS}

The Anti-ChAT polyclonal antibody to Human placental (AB143) enzyme was purchased from Chemicon Co (USA) and anti rabbit $\operatorname{IgG}(\mathrm{H}+\mathrm{L})$ - FITC conjugated was obtained from GIBCO (USA); $\left[{ }^{3} \mathrm{H}\right] \mathrm{AcCoA}(4.0 \mathrm{Ci} / \mathrm{mmol})$ from Amersham (England); AcCoA from Sigma Chemical Co (USA). All other chemicals were of analytical grade.

\section{Denervation of the Electric Organ}


An animal (0.8 - $1 \mathrm{~m}$ long) was anesthetized in ice-cold water containing $2.0 \%$ urethane, and submitted to a surgical denervation as previously described (Nesralla-Lobão et al. 1980). Briefly, this procedure consists of a longitudinal incision on the dorsolateral anterior part of the fish by sectioning of the nerves (about 20 nerves) that innervate the electric organ coming from the spinal cord. During the surgery, the fish was maintained on artificial breathing and preserving the metabolic activities. After 30 and 60 days, the eels were anesthetized and then killed by decapitation. Both denervated and contralateral normal main organs were immediately removed.

\section{Choline Acetyltransferase}

\section{IMMUNOHISTOCHEMISTRY}

Fragments of the main electric organ (normal and denervated) were prepared for immunohistochemistry. They were incubated for 1 hour in a fixative solution containing $4 \%$ paraformaldehyde in $0.1 \mathrm{M}$ phosphate buffer, $\mathrm{pH} 7.4$ (PB), and then in $0.1 \mathrm{M}$ phosphate buffer, with $0.015 \mathrm{M} \mathrm{NaCl}$ (PBS), containing 20\% sucrose, for 2 hours, and finally, in $30 \%$ sucrose PBS solution overnight. Sections of $10 \mu \mathrm{m}$ thickness were obtained after cutting the tissue fragments on a freezing ultramicrotome (Ultracut Reichert). The sections were preincubated with $50 \mathrm{mM}$ $\mathrm{N} \mathrm{H}_{4} \mathrm{Cl}$, for $1 \mathrm{~h}$, washed with PBS-T (PBS plus $0.2 \%$ Tween -20), and subsequently incubated with: a polyclonal anti-ChAT (1:500 dilution) overnight at $40^{\circ} \mathrm{C}$, washed with PBS-T plus $10 \%$ normal goat serum, and with a FITC-labeled goat anti-rabbit IgG (1:20 dilution) for 2 hours at room temperature. The specimens were then mounted onto slides. Controls were made omitting the primary antiserum for each experiment. Normal and denervated sections were examined in a Zeiss 310 Confocal Laser Scanning Microscope (CSLM), by using a 488 argon laser. All images were obtained under the same conditions of brightness and contrast and uniformly processed using Adobe PhotoShop.

\section{Protein Assay}

Protein concentration was determined by the Folinphenol method of Lowry et al. (1951) using bovine serum albumin as a standard.

\section{ENZYMe Assay}

The total extracts and supernatants used in enzymatic assays were obtained by the method of Somló et al. (1977) modified. Using the radiochemical method of Fonnun (1975), with [3H] AcCoA as substrate, we performed the assay for choline acetyltransferase activity. The substrate medium was as follows: $64 \mathrm{mM}$ sodium phosphate buffer, $\mathrm{pH} 7.6$; $384 \mathrm{mM} \mathrm{NaCl} ; 10 \mathrm{mM}$ choline chloride; $25 \mathrm{mM}$ NaEDTA; $10 \mathrm{mM}$ eserine sulfate and $12 \mu \mathrm{MAcCoA}$. To the assay tube containing $10 \mu \mathrm{l}$ of substrate mixture, $20 \mu \mathrm{l}\left[{ }^{3} \mathrm{H}\right] \mathrm{AcCoA}(0.1 \mu \mathrm{Ci})$ was added plus $20 \mu \mathrm{g}$ of protein, at intervals of 30 seconds, at $37^{\circ} \mathrm{C}$, for 15 minutes. The reaction was stopped by addition of $50 \mathrm{mM}$ NaEDTA plus $2 \mathrm{ml}$ of Kalignost solution $(5 \mathrm{mg} / \mathrm{ml}$ tetraphenylborate in acetonitrile). The synthesis of $\left[{ }^{3} H\right]$ ACh was measured in a liquid scintillation Packard apparatus (Model 1600 TR), and the activity is expressed as nmoles ACh formed per minute per mg of protein. Each assay was made in triplicate.

\section{RESULTS}

The presence of choline acetyltransferase (ChAT) was observed by immunofluorescence in the cytoplasm of the electrocyte from electric organ of $E$. electricus (L.) either in normal (Figs. 1a,b and 2a,b) as denervated tissues sections (Figs. 1c,d and 2c,d). As shown in Figures 1a,c and 2a,c the ChAT distribution is mainly cytoplasmic since we hardly observe the ChAT bound to membrane. The reactivities for ChAT in both sections of normal and denervated tissues resulted in fluorescence different patterns after 30 days. Controls concerning incubation only with the second antibody showed no labeling (data not shown). In Figures $1 \mathrm{~d}$ and $2 \mathrm{~d}$, is showing a morphological disorganization of the tissue after denervation when compared with normal tissue (Fig. 1b and 2b). The histochemical distribution 

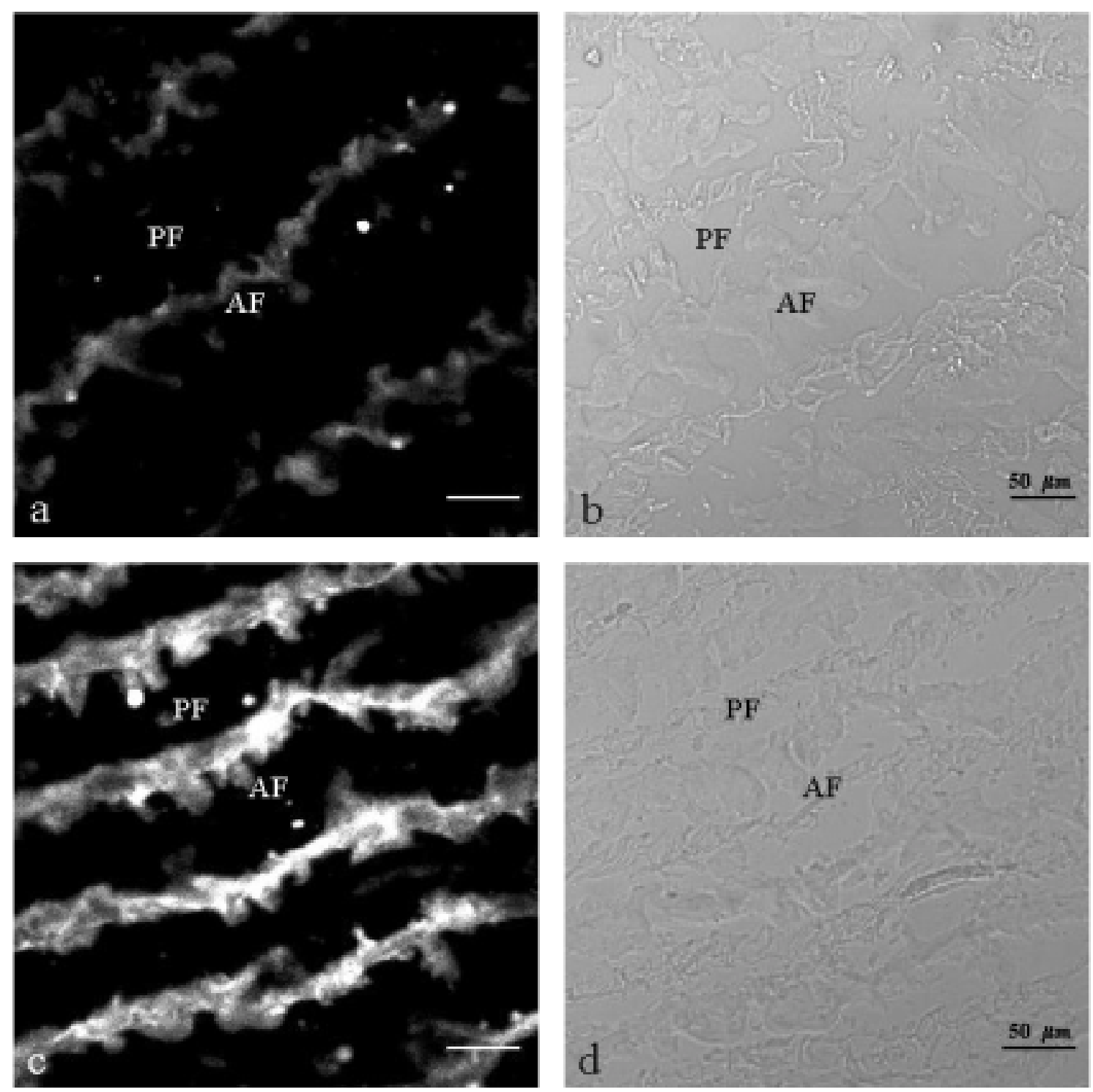

Fig. 1a-b - Thin section $(10 \mu \mathrm{m})$ of normal contralateral electric tissue; a: immunolabelled with policlonal antibody anti-ChAT. Immunoreactivity is essentially cytoplasmatic; b: phase contrast. AF; anterior face, PF; posterior face. Fig. 1c-d - Thin section $(10 \mu \mathrm{m})$ of denervated electric tissue (30 days); c: immunolabelled with policlonal antibody anti-ChAT. A high increase of labelling in the cytoplasm is observed; d: phase contrast. AF; anterior face, PF; posterior face.

of ChAT seems to be highly increased on the cytoplasm of denervated electric tissue section of 30 days (Fig.1c), when compared with the normal (Fig. 1a). 60 days after denervation, the ChAT distribution showed almost the same pattern in both normal and denervated tissue sections (Figs 2a, c).
Biochemical analysis was performed as an attempt to estimate the enzymatic activity on the total extracts from main electric organ, and the supernatants of microsomal fractions (Table I). The specific activity of ChAT obtained from the electric organ total extracts as well from the supernatants 

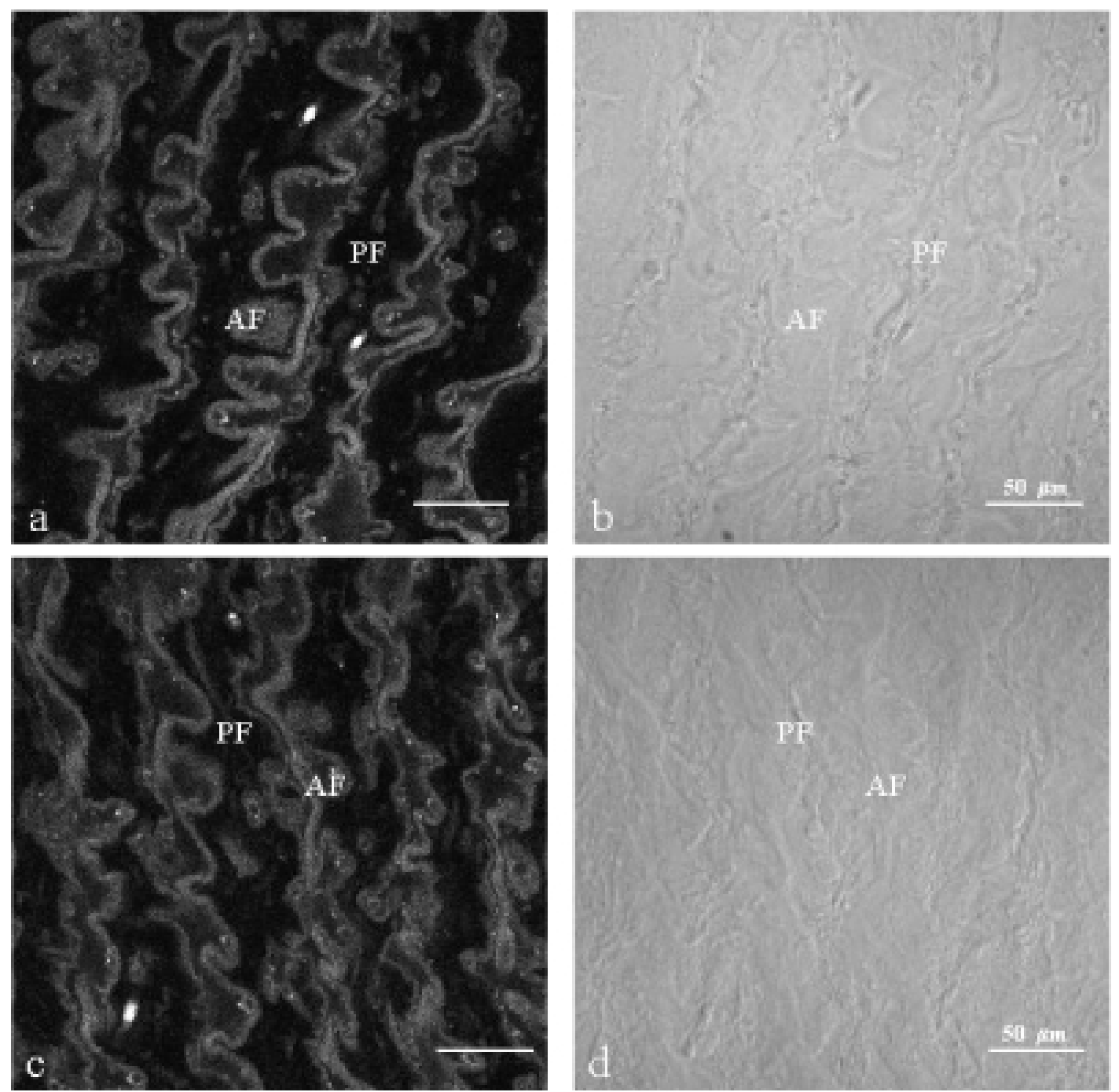

Fig. 2a-b - Thin section $(10 \mu \mathrm{m})$ of normal contralateral electric tissue a: immunolabelled with policlonal antibody anti-ChAT. Immunoreactivity is essentially cytoplasmatic; b: differential interferencial contrast. AF; anterior face, PF; posterior face. Fig. 2c-d - Thin section $(10 \mu \mathrm{m})$ of denervated electric tissue (60 days), c: immunolabelled with policlonal antibody anti-ChAT, The same pattern of labelling in cytoplasm is observed when compared to normal contralateral tissue; d: differential interferencial contrast. AF; anterior face, PF; posterior face.

ranged from 3.80 to $4.50 \mathrm{nmoles} \mathrm{ACh} / \mathrm{min} / \mathrm{mg}$ of protein after 30 days. In animals of 60 days after denervation the ChAT activity showed a decrease from 0,40 to $0,38 \mathrm{nmoles} \mathrm{ACh} / \mathrm{min} / \mathrm{mg}$ of protein, respectively. After denervation these values were of $70 \%$ lower, on both denervated whole organ homogenate and the resulting supernatant.

\section{DISCUSSION}

The study of choline acetyltransferase is of particular interest due to its importance on the cholinergic system (Waser et al. 1989), and also because its deficiency has been correlated with many physiopathological diseases (Kato 1989, Wurtman et al. 1990). The enzyme has been studied with differ- 
TABLE I

ChAT activity in Normal and Denervated main electric organ.

\begin{tabular}{|c|c|c|c|}
\hline & & 30 days* & 60 days* \\
\hline & Normal & $3.80 \pm 0.65$ & $0.40 \pm 0.03$ \\
\hline \multicolumn{4}{|l|}{ Total } \\
\hline Extracts & denervated & $0.81 \pm 0.14$ & $0.11 \pm 0.09$ \\
\hline \multirow{3}{*}{ Supernatants } & Normal & $4.50 \pm 0.87$ & $0.38 \pm 0.25$ \\
\hline & & & \\
\hline & Denervated & $0.71 \pm 0.31$ & $0.14 \pm 0.09$ \\
\hline
\end{tabular}

ent aims by several authors, as molecular properties, while others were interested in investigate its cellular localization (Malthe-Sørenssen \& Fonnun 1972, Polsky \& Shuster 1976, Uyeda et al. 1974, Docherty \& Bradford 1986, Docherty et al. 1987, Levey et al. 1998). In the last years most of the studies on ChAT have been improved, mainly those focusing molecular biology aspects, in mammals (Berrard et al. 1987, Toussaint et al. 1992, Shimojo et al. 1998). Some studies carried out in fishes by using anti-ChAT antibodies have brought detailed information on the cholinergic system (Zottoli et al. 1987, 1988, Brantley \& Bass 1988). Although catalytic activity ascribed to this enzyme has been observed in non-neural tissues, including placenta (Hersh \& Peet 1978), spermatozoa (Bishop et al. 1976), plants (Barlow \& Dixon 1973) and bacteria (White \& Cavallito 1970), its functional significance in such tissues is unknown. As ChAT appears to be present in the cholinergic neuron, it has generally been accepted that the enzyme does not represent the rate-limiting step for ACh biosynthesis. The detection of choline acetyltransferase by antibody is very specific as recently described by Nunes-Tavares and Hassón-Voloch (1998) who observed through western blotting analysis a single band with ChAT purified from electric organ. During the past 10 years, research efforts have focused on the regulatory control of this enzyme. The main characteristic of ChAT regulation is centered on the temporal and spatial control of transcription (Hersh \& Wu 1994). The content of ACh in tissues with cholinergic innervation is very stable. If the release of $\mathrm{ACh}$ is augmented as a consequence of increased functional activity of mammalian cholinergic neurons, the $\mathrm{ACh}$ is replaced almost immediately by new synthesis (MacIntosh \& Collier 1976, Tucek 1982). However, the resynthesis is slower in piscine electric organ (Dunant et al. 1974, 1977). The denervation of the electric organ from Electrophorus electricus (L.) demonstrated a differential distribution, either qualitatively as quantitatively, of choline acetyltransferase when compared with the normal organ, which in turn may have been caused by the loss of electrogenic stimulus in the tissue, as demonstrated in striated muscles from mammals (Lebherz 1984). Generally, a structural degeneration occurs, and the resynthesis of enzymes that are involved in specific tasks increases (Falcato-Ribeiro et al. 1980). Other authors demonstrated a heterologous expression for ChAT in fishes and other species (Falcato-Ribeiro et al. 1980, Gundersen et al. 1985, Berrard et al. 1986, 1987, McCaman et al. 1988, Brice et al. 1989). This mechanism of increase in the enzyme synthesis can be observed in the denervated organ sections: during the disorganization process that is provoked by denervation the molecular structure may be affected, but some epitopes are maintained, and could be even more exposed and in this way the immunofluorescence 
is markedly stronger. However, after 60 days of denervation there is a significant similarity of labeling between the normal and denervated tissues showing recovery of metabolism; other authors have also observed this feature for other important enzymes of the metabolic pathway (Falcato-Ribeiro et al. 1980, Torres-DaMatta et al. 1985, HazanCarneiro \& Hassón-Voloch 1983). We have also compared the enzymatic activity of ChAT with its immunohistochemical staining. Biochemical alterations produced by denervation were observed on total electric organ extracts and supernatants from microsomal membrane preparations. The comparative analysis between normal and denervated organ sections demonstrated that changes due to denervation might increase ChAT mRNA level in 30 days. Likewise, the immunohistochemistry assay here used showed that the spatial distribution of the enzyme molecules is maintained. Our results strongly suggest that many cholinergic neurons survive the injury intact but shrink as recently described by Naumann et al. (1994). Studies made by Falcato-Ribeiro and Chagas Filho (1975) on denervated muscles showed modifications in the protein profiles. Our results reinforce the idea of alterations caused by denervation on the binding between ChAT antigen and antibody used. The observed increase of binding capacity in denervated tissue sections of 30 days and its recovery after 60 days could possibly be explained as a result of an alteration of electroplate structure, evoked by the a long absence of stimulation by the nerve, which is reflected in the protein synthesis.

The paradigm observed after denervation, i.e., an increase of expression of choline acetyltransferase after 30 days of denervation accompanied by a decrease of activity, and the similarity of labeling between the tissues sections (normal and denervated) after 60 days, are probably easier to identify in the electric tissue due to the slow process of atrophy following the lesion. It is possible that these changes probably represent a readjustment to maintain the basic conditions of performance of the denervated electric organ.

\section{ABBREVIATIONS}

ChAT $=$ Choline acetyltransferase $;$ ACh $=$ Acetylcholine; NaEDTA = Tetrasodium ethylene-diaminetetraacetate; $\mathrm{PB}=$ Phosphate-buffer; $\mathrm{PBS}=$ Phosphate-buffered saline; PBS-T = Phosphate-buffered saline plus Tween-20; $\mathrm{NaCl}=$ Sodium Chloride; Ac$\mathrm{CoA}=$ Acetyl coenzyme A.

\section{ACKNOWLEDGEMENTS}

This work is dedicated to the memory of Dr Carlos Chagas Filho founder of Institute of Biophysics at UFRJ.

This work was supported by grants from Conselho Nacional de Desenvolvimento Científico e Tecnológico (CNPq), Conselho de Ensino para Graduados da UFRJ (CEPEG-UFRJ); Financiadora de Estudos e Projetos (FINEP) and Fundação Carlos Chagas Filho de Amparo à Pesquisa do Estado do Rio de Janeiro (FAPERJ).

We thank Célia M.B. Silva for helpfull comments; Dr. Elaine Gomes Quintana and Dr Fernando Costa e Silva for critical reading of the manuscript, Dr Renato A. DaMatta for helpful assistence and Sérgio L. Carvalho for technical assistance.

\section{REFERENCES}

Aigner TG \& Mishrin M. 1986. The effects of physiostigmine and scopolamine on recognition memory in monkeys. Behav Neural Biol 45: 81-87.

BARLOW RB \& DixON RO. 1973. Choline acetyltransferase in the Nettle Urtica dioica L. Biochem J 132: $15-18$.

BARTus RT \& BeER RD. 1982. Cholinergic hypothesis of geriatric memory dysfunction. Science 217: 408414 .

Berrard S, Biguet NF, Gregoire D, Blanot F, Smith J \& Mallet J. 1986. Synthesis of catalitically active choline acetyltransferase in Xenopus oocytes injected with messenger RNA from rat central nervous system. Neurosci Lett 72: 93-98. 
Berrard S, Brice A, Lottspeich F, Braun A, Bard YA \& MALlET J. 1987. cDNA cloning and complete sequence of porcine choline acetyltransferase; in vitro translation of the corresponding RNA yields an active protein. Proc Natl Acad Sci USA 84: 9280-9284.

Bishop MR, Sastry BV, Schmidt DE \& Harbison RD. 1976. Ocurrence of Choline and other quartenary ammonium compounds in mammalian spermatozona. Biochem Pharmacol 25: 1617-1622.

Brantley RK \& Bass AH. 1988. Cholinergic neurons in the brain of teleost fish (Porichthys notatus) located with a monoclonal antibody to choline acetyltransferase. J Comp Neurol 275 (1): 87-105.

Brice A, Berrard S, Raynaud B, Ansieau S, Copolla T, Weber MJ \& Mallet J. 1989. Complete sequence of cDNA encoding an active rat choline acetyltransferase: a tool to investigate the plasticity of cholinergic phenotype expression. J Neurosci Res 23: $266-273$.

Chagas Filho C, Penna-Franca E, Hassón-Voloch A, Crocker C, Nishie K \& Garcia E. 1957. Studies of the mechanism of curarization. An Acad Bras $C i$ 29: 53-58.

Costa ML, Mermelstein CS, Moura Neto V \& ChaGAS Filho C. 1988. Desmin expression in the electric organs of Electrophorus electricus (L.). J Cell Biochem (Supp). 12c: 323-329.

Costa ML, Oliveira MM, Alberti JR O, Moura Neto V \& Chagas Filho C. 1986. Characterisation de la desmine dans l'organe électrique de l'Electrophorus electricus (L.). C R Acad Sci Paris, 303 (série III): 547-550.

Couceiro A \& Ackerman M. 1948. Sur quelques aspects du tissu électrique de l'Electrophorus electricus (L.). An Acad Bras Ci XX, 4: 383-395.

Couceiro A, DE Almeida DF \& Freire JR. 1953. Localisation histochimique de l'Acetylcholinesterase dans le tissue électrique de l'Electrophorus electricus (L.). An Acad Bras Ci 25: 205-214.

DOCHERTY M \& BRADFORd HF. 1986. A cell-surface antigen of cholinergic nerve terminals recognized by antisera to choline acetyltransferase. Neurosci Lett 70: $234-238$.
DOCHERTY M, BRADFORD HF \& Wu JY. 1987. The preparation of highly purified GABAergic and cholinergic synaptosomes from mammalian brain. Neurosc Lett 81: 232-238.

Dunant Y, Gautron J, Israel M, Lesbats B \& MaNARANCHE R. 1974. Evolution de la décharge de l'organe électrique de la Torpille et variations simultanées de l'acetylcholine au cours de la stimulation. J Neurochem 23: 635-643.

Dunant Y, Israel M, Lesbats B \& Manaranche R. 1977. Oscillation of acetylcholine during nerve activity in the Torpedo electric organ. Brain Res 125: 123-140.

Esquibel MA, Alonso I, Meyer H, Oliveira Castro G \& Chagas Filho C. 1971. Quelques aspects de l'histogénèse et de l'ontogénèse des organes electriques chez l'Electrophorus electricus (L.). $C R$ Acad Sci Paris, (Série D) 273: 196-199.

Falcato-Ribeiro AF \& Chagas Filho C. 1975. Effect de la dénérvation sur le métabolisme macromoleculaire chez le tissu éléctrique de l'Electrophorus electricus (L.). C R Acad Sci Paris, (Série D) 281: $1425-$ 1430.

Falcato-Ribeiro AF, Chagas Filho C \& Couceiro A. 1977. Evidência histoenzimológica de modificações na atividade de algumas enzimas em tecido eletrogênico desnervado. Rev Bras Biol 37 (4): 791798 .

Falcato-Ribeiro AF, Chagas Filho C \& Couceiro A. 1980. Histoenzymological evidence for the modification in the activity of some enzymes in the denervated electrogenic tissue of Electrophorus electricus (L.). IRCS Medical Science 8: 776-777.

FonNUn FA. 1975. Rapid radiochemical method for the determination of Choline Acetyltransferase. $J$ Neurochem 24: 407-409.

Gundersen CB, Jenden DJ \& Miledi R. 1985. Choline acetyltransferase and acetylcholine in Xenopus oocytes injected with mRNA from the electric lobe of Torpedo. Proc Natl Acad Sci USA 82: 608-611.

Hazan-Carneiro LV \& Hassón-Voloch A. 1983. Creatine kinase from the electric organ of Electrophorus electricus (L.). Isozyme analysis. Int J Biochem 15: 
$111-114$

Hersh LB \& PeEt M. 1978. Effect of salts on the physical and kintic properties of human placental choline acetytransferase. J Neurochem 30: 1087-1093.

Hersh LB \& Wu D. 1994. Choline Acetyltransferase: Celebrating its fiftieth year. J Neurochem 62: $1653-$ 1663.

Hersh LB \& Wu D. 1995. Activation of Choline Acetyltransferase by limited proteolysis. J Biol Chem 270: 19395-19401.

Kato T. 1989. Choline Acetyltransferase activities in single spinal motor neurons from patients with Amyotrophic Lateral Sclerosis. J Neurochem 52: 636640.

Kuhl de, Minoshima S, Fessler JA, Frey KA, Foster NL, Ficaro EP, Wieland DM \& Kooeppe RA. 1996. In vivo mapping of cholinergic terminals in normal aging, Alzeheimer's disease and Parkinson's disease. Ann Neurol 40: 399-410.

LEBHERZ HG. 1984. Neuronal control of synthesis of specific proteins in muscle fibers. Trends in Biochem. Sci.. August, 351-354.

Levey AI, Gilmor ML, Count SE \& Wiley RG. 1998. Coordinate expression of the vesicular acetycholine transporter and choline acetyltransferase following septohippocampal pathway lesions. J Neurochem 71: 2411-2420.

LoEwi O. 1921. Uber humorale ubertragarkeit der hirzenwickung. Pflugers Arch 189: 239-242.

Lowry OH, Rosenbrough NJ, Farr AL \& Randall RJ. 1951. Protein measurement with the Folin phenol reagent. J Biol Chem 193: 265-275.

Machado RD, de Souza W, Cotta-Pereira G \& Oliveira Castro G. 1976. On the fine structure of the electrocyte of Electrophorus electricus (L.). Cell Tiss Res 174: 355-366.

Macintosh FC \& Collier B. 1976. Neurochemistry of cholinergic terminals in Neuromuscular junction. Handbook of Experimental Pharmacology, New series, (ed. Zaimis), Springer-Verlag, Berlin. 42: 99228.
McCaman Re, Carbini L, Maines V \& Salvaterra PM. 1988. Single RNA species injected in Xenopus oocyte directs the synthesis of active choline acetyltransferase. Mol Brain Res 3: 107-114.

Malthe-Sørenssen D \& Fonnun F. 1972. Multiple forms of Choline Acetyltransferase in several species demonstrated by Isoelectric Focusing. Biochem $J$ 127: 229-236.

Martins-Ferreira H \& Couceiro A. 1951. Comportement du tissue électrique de l'Electrophorus electricus (L.) en conséquence de la dénervation. An Acad Bras Ci 23 (4): 376-385.

Molenaar PC, Newsom-Davis J, Polak L \& Vicent A. 1981. Choline Acetyltransferase in skeletal muscle from patients with Myasthenia Gravis. J Neurochem 37(5): 1081-1088.

Nachmansohn D \& Machado AL. 1943. The formation of acetylcholine. A new enzyme choline acetylase. $J$ Neurophysiol 6: 397-403.

Naumann T, Kermer P \& Frotcher M. 1994. Fine structure of rat septohippocampal neurons. III. Recovery of choline acetyltransferase immunoreactivity after fimbria-fornix transection. J Comp Neurol 350: 161-170.

Nesralla-Lobão H, Gomes-Quintana E, Machado RD \& Chagas Filho C. 1980. Cholinergic mambranes from normal and denervated electric organ of Electrophorus electricus (L.). IRCS Med. Sci Biochem 8: 450-451.

Nunes-Tavares N \& Hassón-Voloch A. 1998. Choline acetyltransferase from electric organ of Electrophorus electricus (L.). Physicochemical characterization and immunochemical identification. Zeits Naturf 53c: $407-415$.

Polsky R \& Shuster L. 1976. Preparation and characterization of two isozymes of Choline Acetyltransferase from Squid Head Ganglia. (II- SelfAssociation, Molecular weight determinations and Studies with inactivating antisera. Biochem Biophys Acta 445: 43-66.

Rand JB, Alfonso A, Grundahl K \& McManus JR. 1994. Cloning and characterization of the choline acetyltransferase structural gene (cha-1) from $C$. 
elegans. J Neurosci 14 (4): 2290-2300.

Rossier J. 1977. Choline Acetyltransferase: A review with special reference to its cellular and subcellular localization. Int Rev Neurobiol 20: 284-337.

Ruberg M, Mayo W, Brice A, Duyckaerts C, Hauw JJ, Simon H, Lemoal M \& Agid Y. 1990. Choline Acetyltransferase activity and $\left[{ }^{3} \mathrm{~h}\right]$ Vesamicol binding in the temporal cortex of patients with Alzheimer's disease. Parkinson 1s disease and rats with basal forebrain lesions. Neurosci 35: 327-333.

Salvaterra PM, Kouji Yasuyama \& Toshihiro Kitaмото. 1995. Localization of Choline acetyltransferase-expressing neurons in the larval visual system of Drosophila melanogaster. Cell Tissue Res 282: 193-202.

Schwartz IR, Pappas GD \& Bennet MVL. 1975. The structure of electrocytes in weakly electric teleosts. J Neurocytol 4: 87-114.

Shimojo M, Wu D \& Hersh LB. 1998. The cholinergic gene locus is coordinately regulated by protein kinase A II in PC12 cells. J Neurochem 71: 1118-1126.

Somló C, Souza W, Machado RD \& Hassón-Voloch A. 1977. Biochemical and Cytochemical localisation of ATPases on the membranes of the electrocyte of Electrophorus electricus (L.). Cell Tiss Res 185: 115-128.

Torres da Matta J, Hassón-Voloch A \& Hargreaves AB. 1975. Lactate deshidrogenase from the electric organ of Electrophorus electricus (L.) - Isoenzyme analysis. Comp Biochem Physiol 52B: 451-454.

Torres da Matta J, Silva CB, da Matta AN \& Hassón-Voloch A. 1985. Effect of denervation on the glycolitic metabolism of the main electric organ of Electrophorus electricus (L.). Comp Biochem Physiol 81B: 969-973.
Toussaint JL, Geoffroy V, Scmitt N, Werner A, GarNIER JM, SIMONI P \& KEMPF J. 1992. Human choline acetyltransferase (ChAT): partial gene sequence and potencial control regions. Genomics 12: 412-416.

TuceK S. 1982. The synthesis of Acetylcholine in skeletal muscles of the rat. J Physiol 322: 53-69.

Uyeda CT, Eng LF, Chao LP \& Wolfgran F. 1974. Antibody to bovine choline acetyltransferase and immunofluorescent localisation of the enzyme in neurons. Nature 250: 243-245.

Waser G, Riggio G \& Raeber AJ. 1989. Purification and isolation of choline acetyltransferase from the electric organ of Torpedo marmorata by affinity chromatography. Eur J Biochem 186: 487-492.

White HL \& Cavallito CJ. 1970. Inhibition of bacterial and mammalian choline acetyltransferases by styrylpyridine analogues. J Neurochem 17: 15791589.

WhitTaker VP. 1987. Cholinergic synaptic vesicles from the electromotor nerve terminal of Torpedo. Composition and life cycle. Ann NY Acad Sci 493: 77-91.

Wurtman RJ, Blusztajn JK, Ulus IH, Coviella IL, Buyukuysal RL, Growdon JH \& Slack BE. 1990. Choline metabolism in cholinergic neurons: implications for the pathogenisis of neurodegenerative diseases. Adv Neurol 51: 117-125.

Zottoli SJ, Rhodes KJ \& Mufson EJ. 1987. Comparison of acetylcholinesterase and choline acetyltransferase staining patterns in the optic tectum of the goldfish Carassius auratus. A histochemical and immunocytochemical analysis. Brain Behav Eval 30(34): 143-159.

Zottoli SJ, Danielson PD, Rhodes KJ, Corrodi JG \& Mufson EJ. 1988. Localisation of choline acetyltransferase to somata of posterior lateral line efferents in the goldfish. Brain Res 448(1): 158-161. 